\title{
Bacteriophage PPST1 Isolated from Hospital Wastewater, A Potential Therapeutic Agent Against Drug Resistant Salmonella enterica subsp. enterica serovar Typhi
}

\author{
Pongsak Rattanachaikunsopon and Parichat Phumkhachorn \\ Faculty of Science, Ubon Ratchathani University \\ Thailand
}

\section{Introduction}

Salmonella enterica subsp. enterica serovar Typhi (hereafter referred to as Salmonella Typhi) is a Gram-negative enteric bacillus belonging to the family Enterobacteriaceae. It is a facultative anaerobe that is motile by peritrichous flagella. The bacterium is catalase positive, oxidase negative. It produces no gas when grown in Triple Sugar Iron (TSI) broth, which is used to differentiate it from other Enterobacteriaceae (Murray, 1994).

The bacterium is restricted to humans and is not known to have a reservoir in animals. Thus, the transmission of $S$. Typhi has only been shown to occur from person to person via fecal-oral route. Infection of $S$. Typhi leads to the development of typhoid, or enteric fever. This disease is characterized by the sudden onset of a sustained and systemic fever, severe headache, nausea, and loss of appetite. Other symptoms include constipation or diarrhea, enlargement of the spleen, possible development of meningitis, and/or general malaise. The disease has caused many deaths in developing countries where sanitation is poor and is spread through contamination of water and undercooked food (Murray, 1994).

Treatment of typhoid fever relies mainly on such antibiotics as chloramphenicol, ampicillin and trimethoprim-sulfamethoxazole (Rowe et al., 1997; Trung et al., 2007); however, the success of the antibiotic based therapeutic approach has currently been limited because of the emergence of multidrug resistant strains of $S$. Typhi. Owing to the development of bacterial resistance to chloramphenicol during the 1970s and 1980s, treatment with this drug was widely replaced by ampicillin and trimethoprim-sulfamethoxazole; however, by the 1980s and 1990s, S. Typhi developed resistance simultaneously to all drugs used for firstline treatment, namely, chloramphenicol, ampicillin and trimethoprim-sulfamethoxazole (Trung et al., 2007). These multidrug resistant S.Typhi strains have been found to be responsible for numerous outbreaks in many countries in the Indian subcontinent, Southeast Asia, and Africa (Rowe et al., 1997). In light of the evidence of the rapid global spread of drug resistant $S$. Typhi strains, the need to find new antibiotics to treat diseases caused by the bacteria is of paramount importance. However, the past record of rapid emergence of resistance to newly introduced antibiotics indicates that even new families of antibiotics will 
have a short life expectancy (Coates et al., 2002). For this reason, researchers are increasingly turning their attention to alternative therapeutic approaches to combat drug resistant $S$. Typhi. One of the promising approaches is bacteriophage therapy or phage therapy.

Bacteriophages or phages are viruses that infect bacteria. Lytic or virulent bacteriophages have been considered to be a new class of antibacterial agents because they undergo rapid growth, disrupt bacterial metabolism and reproduction, and lyse the bacterial cells. They have been used for therapeutic purposes since the 1920s. Several studies have shown that bacteriophages could be used successfully for therapeutic purposes both in humans and animals (Bruttin \& Brussow, 2005; Chhibber et al., 2008; Deresinski, 2009; Nakai \& Park, 2002). In addition, there have been several reports showing the ability of lytic bacteriophages to kill drug resistant bacteria (Capparelli et al., 2007; Thamniamton et al., 2010; Vinodkumar et al., 2005). Therefore, it is of interest to find a bacteriophage for use as a therapeutic agent to control drug resistant $S$. Typhi.

In this study, a bacteriophage specific to drug resistant $S$. Typhi was isolated from hospital wastewater. It was also characterized with respect to host range, adsorption, thermal and $\mathrm{pH}$ sensitivity, one step growth, and morphology, genome and protein composition. The bacteriophage from this study may be useful as a potential therapeutic agent for controlling drug resistant $S$. Typhi infections.

\section{Materials and methods}

\subsection{Bacterial strains and culture conditions}

The bacterial strain used as the indicator strain for the isolation, propagation, and characterization of the bacteriophage named PPST1 was drug resistant Salmonella enterica subsp. enterica serovar Typhi strain SSH1 (hereafter referred to as S. Typhi SSH1) which was kindly donated by Sappasitiprasong Hospital, Ubon Ratchathani, Thailand. The bacterial strain was confirmed as S. Typhi by the API $20 \mathrm{E}$ test kit (bioMerieux Industry, Hazelwood, MO, USA). Antibiotic susceptibility testing by Kirby-Bauer's method revealed that $S$. Typhi SSH1 was resistant to most of the commonly-used drugs including chloramphenicol, ampicillin, trimethoprim, tetracycline, streptomycin, sulfanilamideand ciprofloxacin. Bacterial strains used to test the host range of the bacteriophage PPST1 are listed in Table 1. All of them were obtained from the American Type Culture Collection (ATCC).

All bacteria were maintained on Brain Heart Infusion (BHI) agar (Oxoid, Wesel, Germany). Fresh colonies were cultured and subcultured in BHI broth at $37^{\circ} \mathrm{C}$. Stock cultures of all bacteria were stored as a frozen culture at $-80^{\circ} \mathrm{C}$ in $\mathrm{BHI}$ broth containing $20 \%$ glycerol ( $\mathrm{vol} / \mathrm{vol})$.

\subsection{Bacteriophage isolation and purification}

The water sample for bacteriophage isolation was collected from wastewater treatment tank located at Sappasitiprasong Hospital, Ubon Ratchathani, Thailand. The sample was stored at $4^{\circ} \mathrm{C}$ overnight to allow larger suspended sediments to settle out. The crudely clarified sample was centrifuged at 4,500 $\mathrm{xg}$ for $10 \mathrm{~min}$ to remove bacterial cells and debris. The supernatant was passed through a 0.22- $\mu \mathrm{m}$-pore-size membrane filter (SartoriusAG, Gottingen, Germany). For bacteriophage enrichment, the filtrate was added to an equal 
volume of double strength BHI broth containing log phase S. Typhi SSH1 cells (final concentration of $10^{6} \mathrm{CFU} / \mathrm{ml}$ ). After incubation at $37^{\circ} \mathrm{C}$ overnight, the culture was centrifuged at 4,500 xg for $10 \mathrm{~min}$ and the supernatant was filtered through a $0.22-\mu \mathrm{m}$-poresize membrane filter. The presence of a lytic phage in the filtrate was examined by using the double layer method with some modifications (Paterson et al., 1969). One hundred $\mu 1$ of the filtrate was mixed with $400 \mu \mathrm{l}$ of a log phase culture of $S$. Typhi SSH1 and incubated at $37^{\circ} \mathrm{C}$ for $30 \mathrm{~min}$. The mixture was added into $4.5 \mathrm{ml}$ of molten BHI soft agar $(0.7 \%$ agar $)$ which was already cooled down to $50^{\circ} \mathrm{C}$, mixed gently, and poured onto a $\mathrm{BHI}$ agar plate $(1.5 \%$ agar). The plate was left to stand at room temperature for $30 \mathrm{~min}$ to allow the top agar to solidify. The presence of a lytic bacteriophage in the form of plaques was detected after incubation of the plate at $37^{\circ} \mathrm{C}$ overnight.

For bacteriophage purification, a single plaque was picked with a sterile glass Pasteur pipette, and put into a log phase culture of $S$. Typhi SSH1. After incubated at $37^{\circ} \mathrm{C}$ overnight, the bacteriophage-host mixture was centrifuged at 4,500 xg for $10 \mathrm{~min}$ and filtered through a 0.22$\mu \mathrm{m}$-pore-size membrane filter. The filtrate was subjected to the double layer method as mentioned above. Three repeated rounds of single plaque isolation and re-inoculation were performed. The bacteriophage was eluted from the final resulting plate by adding $5 \mathrm{ml}$ of SM buffer (50 mM Tris- $\mathrm{HCl}$, pH 7.5, $99 \mathrm{mM} \mathrm{NaCl}, 8 \mathrm{mM} \mathrm{MgSO}_{4}, 0.01 \%$ gelatin) on top of the plate and incubated at room temperature for $4 \mathrm{~h}$ with shaking. The bacteriophage containing buffer retrieved from the plate was centrifuged at 4,500 xg for $10 \mathrm{~min}$ and filtered through a $0.22-\mu \mathrm{m}-$ pore-size membrane filter. The resulting filtrate was called bacteriophage suspension.

\subsection{Bacteriophage titer determination}

The bacteriophage containing solution was serially diluted in SM buffer. Each dilution was subjected to plaque assay using the double layer method as mentioned earlier. Plaques were counted in the plate containing 50-300 plaques and expressed as plaque forming unit per milliliter $(\mathrm{PFU} / \mathrm{ml})$.

\subsection{Bacteriophage host range determination}

The spot test method described by Chang et al. (2005) was used for bacteriophage host range determination using the bacteria listed in the Table 1 as hosts. Each bacterial strain was grown overnight in BHI broth. One hundred $\mu \mathrm{l}$ of the culture was mixed well with $4 \mathrm{ml}$ of $\mathrm{BHI}$ soft agar $(0.7 \%$ agar) and then overlaid on the surface of the BHI agar (1.5\% agar). After solidication, $10 \mu \mathrm{l}$ of the bacteriophage suspension was spotted onto the top agar layer, which was then incubated at $37^{\circ} \mathrm{C}$ overnight. Bacterial sensitivity to the bacteriophage was notified by a clear zone at the spot where the phage suspension was deposited.

\subsection{Bacteriophage adsorption study}

The bacteriophage adsorption was studied according to the protocol of Lu et al. (2003) with some modifications. A S. Typhi SSH1 culture with the concentration of $10^{8} \mathrm{CFU} / \mathrm{ml}$ was infected with the bacteriophage suspension to give a multiplicity of infection (MOI) of 0.01 and incubated at $37^{\circ} \mathrm{C}$. Aliquots were taken at $5 \mathrm{~min}$ intervals (up to $30 \mathrm{~min}$ ) after infection and immediately centrifuged at $4,500 \mathrm{xg}$ for $10 \mathrm{~min}$ to sediment the bacteriophage-adsorbed cells. filtered through a $0.22-\mu \mathrm{m}$-pore-size membrane filter. Filtrates were subjected to 
determination of titer of unadsorbed bacteriophages (residual titer) by the double layer method as mentioned earlier. BHI broth containing only bacteriophage was used as a control. The percentage of adsorption was calculated as follows: [(control titer-residual titer)/control titer] $\times 100 \%$.

\subsection{Thermal and $\mathrm{pH}$ sensitivity test}

The sensitivity of bacteriophage PPST1 to temperature was examined as follows. Nine hundred $\mu \mathrm{l}$ of sterile deionized water was preheated to a desirable temperature, ranging from $50^{\circ} \mathrm{C}$ to $90^{\circ} \mathrm{C}$. One hundred $\mu \mathrm{l}$ of the bacteriophage suspension was added to the preheated water to obtain the final bacteriophage concentration of about at $10^{6} \mathrm{PFU} / \mathrm{ml}$. After heating at the assigned temperatures for $30 \mathrm{~min}$, the solutions were placed in an ice bath. Surviving bacteriophage titer was assayed by the double layer method.

The sensitivity of bacteriophage PPST1 to $\mathrm{pH}$ was also examined. The bacteriophage (at the final concentration of $10^{6} \mathrm{PFU} / \mathrm{ml}$ ) was incubated overnight at $37^{\circ} \mathrm{C}$ in phosphate buffered saline (135 mM NaCl, $1.3 \mathrm{mM} \mathrm{KCl}, 0.5 \mathrm{mM} \mathrm{KH}_{2} \mathrm{PO}_{4}, 3.2 \mathrm{mM} \mathrm{Na}_{2} \mathrm{HPO}_{4}, \mathrm{pH} 7.4$ ), adjusted in steps of $1 \mathrm{pH}$ unit from $\mathrm{pH} 2$ to 12 using $\mathrm{HCl}$ or $\mathrm{NaOH}$ as required. Upon re-adjustment to $\mathrm{pH} 7$, the double layer method was performed to determine bacteriophage titer.

\subsection{Study of one-step growth kinetics}

One step growth experiment was performed as described by (Caso et al., 1995) with some modifications. Briefly, $10 \mathrm{ml}$ of log phase culture of S. Typhi SSH1 was harvested by centrifugation at 4,500 xg for $10 \mathrm{~min}$ and resuspended in $5 \mathrm{ml}$ of fresh BHI broth in order to obtain a final concentration of $10^{8} \mathrm{CFU} / \mathrm{ml}$. To this suspension, $5 \mathrm{ml}$ of the bacteriophage suspension was added in order to have a MOI of 0.01 and the bacteriophage was allowed to adsorb for $30 \mathrm{~min}$ at $37^{\circ} \mathrm{C}$. The mixture was centrifuged at $4,500 \times \mathrm{g}$ for $10 \mathrm{~min}$, and the pellets containing infected cells were resuspended in pre-warmed $\left(37^{\circ} \mathrm{C}\right) \mathrm{BHI}$ broth, followed by incubation at $37^{\circ} \mathrm{C}$. Samples were taken at 10 -min intervals (up to $3 \mathrm{~h}$ ) and immediately diluted, and bacteriophage titers were determined by the double layer method.

\subsection{Examination of bacteriophage morphology}

The morphology of bacteriophage PPST1 was examined by transmission electron microscopy. Bacteriophage particles were fixed by mixing $25 \mu \mathrm{l}$ of the bacteriophage suspension with $25 \mu \mathrm{l}$ of $50 \%$ glutaraldehyde in $4 \%$ paraformaldeyde. A 5 - $\mu$ l aliquot of this mixture was placed on a carbon Formvar-coated copper grid (Proscitech, Brisbane, Queenland, Australia) and allowed to adsorb for $5 \mathrm{~min}$ at room temperature. The bacteriophage was negatively stained with $0.5 \%$ uranyl acetate for 2 min then inspected with a Philips EM 300 electron microscope (Philips, Eindhoven, the Netherlands) operated at $60 \mathrm{kV}$. The bacteriophage size was determined from the average of five independent measurements.

\subsection{Analysis of bacteriophage proteins}

The protein composition of bacteriophage PPST1 was examined by sodium dodecyl sulfatepolyacrylamide gel eectrophoresis (SDS-PAGE) using NuPAGE Novex gel system 
(Invitrogen, Carlsbad, CA, USA). A 26- $\mu$ l aliquot of the bacteriophage suspension was mixed with $10 \mu \mathrm{l}$ of sample buffer and $4 \mu \mathrm{l}$ of reducing agent. The mixture was heated in boiling water for $10 \mathrm{~min}$ and then subjected to electrophoresis on a $4-12 \%$ Bis-Tris gel at 200 $\mathrm{V}$ and $120 \mathrm{~mA}$ for $35 \mathrm{~min}$. The protein bands were stained with Coomassie blue G-250 (Sigma-Aldrich, St. Louis, MO, USA), followed by destaining with a solution containing $50 \%$ methanol and $1 \%$ acetic acid.

\subsection{Analysis of bacteriophage nucleic acid}

Bacteriophage nucleic acid was extracted by using PureLink Viral RNA/DNA Mini Kit (Invitrogen, Carlsbad, CA, USA) according to the protocol provided by the manufacturer. The purified nucleic acid was tested for sensitivity to Ribonuclease A, Nuclease $S_{1}$ and restriction enzyme PstI (all from Sigma-Aldrich, St. Louis, MO, USA), according to the supplier's recommendations. The results were analyzed by $0.8 \%$ agarose gel electrophoresis.

The genome size of the bacteriophage PPST1 was determined by pulse-field gel electrophoresis (PFGE) of the purified bacteriophage nucleic acid. The electrophoresis was carried out with $0.8 \%$ agarose gel in $0.5 x$ Tris-borate-EDT buffer at $15^{\circ} \mathrm{C}$ for $15 \mathrm{~h}$, using switch time ramped from 1 to $12 \mathrm{~s}$ and a voltage of $6 \mathrm{~V} / \mathrm{cm}$. The PFGE size standard used was Low range PFG marker (New England Biolabs, Ipswich, MA, USA).

\section{Results}

\subsection{Bacteriophage isolation}

A bacteriophage was isolated from the hospital wastewater by the double layer method using $S$. Typhi SSH1 as a host bacterial strain. The bacteriophage produced clear plaques on the lawn of the host bacterial strain, indicating that it was a lytic or virulent bacteriophage. The plaques were small with an average diameter of $1 \mathrm{~mm}$ (Fig. 1), and the isolated bacteriophage was designated PPST1.

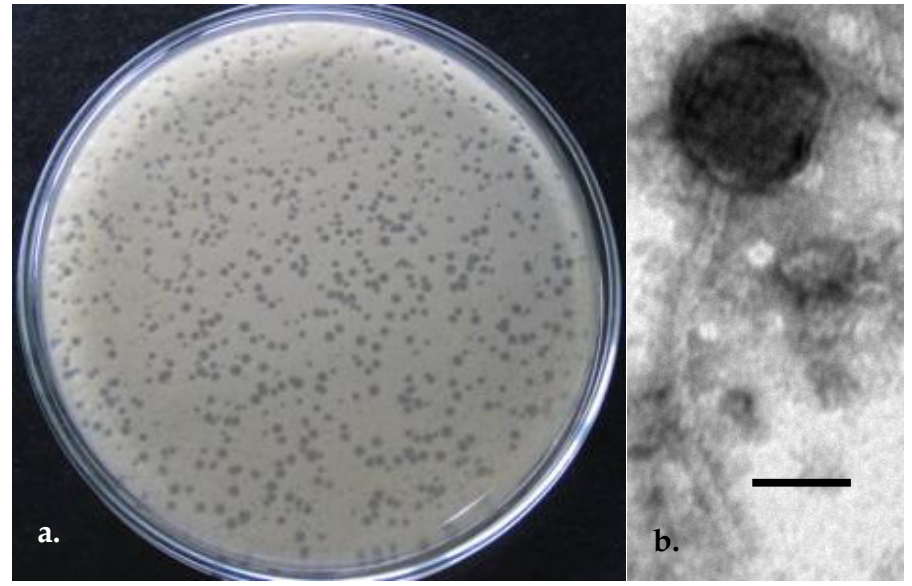

Fig. 1. Plaques on $S$. Typhi SSH1 lawn (a) and transmission electron micrograph (b) of bacteriophage PPST1. Bar $=50 \mathrm{~nm}$ 


\subsection{Bacteriophage host range}

Specifictity of bacteriophage PPST1 to a variety of bacteria was examined by the spot test method. Of all 23 bacterial strains used in this experiment, only S. Typhi SSH1, S. Typhi ATCC 19430, S. Typhi ATCC 19214 were susceptible to the bacteriophage as shown in Table 1. On the other hand, the rest of the tested bacterial strains used in this study were not sensitive to the bacteriophage. Among the three sensitive bacterial hosts, two of them, $S$. Typhi SSH1 and S. Typhi ATCC 19214, are drug resistant strains. These results suggested that the bacteriophage had a broad host range with specificity to $S$. Typhi and the specificity of the bacteriophage was not influenced by the drug-resistance properties of the hosts.

\begin{tabular}{ll}
\hline Bacteria & Lysisa \\
\hline Campylobacter jejuni ATCC 29428 & - \\
Enterobacter aerogenes ATCC 13048 & - \\
Enterococcus faecalis ATCC 51575 (vancomycin resistant) & - \\
Escherichia coli ATCC 11229 & - \\
Escherichia coli O157:H7 ATCC 35150 & - \\
Klebsiella pneumoniae ATCC 4352 & - \\
Listeria monocytogenes ATCC 19111 & - \\
Pseudomonas aeruginosa ATCC 15442 & - \\
Salmonella enterica serovar Choleraesuis ATCC 6958 & - \\
Salmonella enterica serovar Derby ATCC 6960 & - \\
Salmonella enterica serovar Enteritidis ATCC 4931 & - \\
Salmonella enterica serovar Heidelberg ATCC 8326 & - \\
Salmonella enterica serovar Paratyphi A ATCC 9150 & + \\
Salmonella enterica serovar Typhi SSH1 (multidrug resistant) & + \\
Salmonella enterica serovar Typhi ATCC 19430 & + \\
Salmonella enterica serovar Typhi ATCC 19214 (multidrug resistant) & - \\
Salmonella enterica serovar Typhimurium ATCC 6994 & - \\
Salmonella enterica serovar Typhimurium ATCC 700408 (multidrug resistant) & - \\
Salmonella enterica serovar Typhisuis ATCC 8321 & - \\
Shigella flexneri ATCC 29903 & - \\
Staphylococcus aureus ATCC 6538 & - \\
Staphylococcus aureus ATCC 33592 (methicillin resistant) & - \\
Streptococcus pyogenes ATCC 19615 & - \\
\hline
\end{tabular}

a + = clear zone form, - = no clear zone formed

Table 1. Bacterial strains used in this study and their sensitivity to bacteriophage PPST1

\subsection{Bacteriophage adsorption}

The adsorption rate of bacteriophage PPST1 on S. Typhi ST1 is shown in Fig 2. Most of the bacteriophage particles were rapidly adsorbed to host cells within the first 10 minutes of the observation period; after which, the bacteriophage particles were adsorbed into the host cells at a relatively slow rate. Almost all of the bacteriophage particles were adsorbed into the host cells within 30 minutes. The results demonstrated that ca. $80 \%, 90 \%$ and $98 \%$ of bacteriophage PPST1 particles adsorbed to the host cells within $10 \mathrm{~min}, 20 \mathrm{~min}$ and $30 \mathrm{~min}$, respectively. 


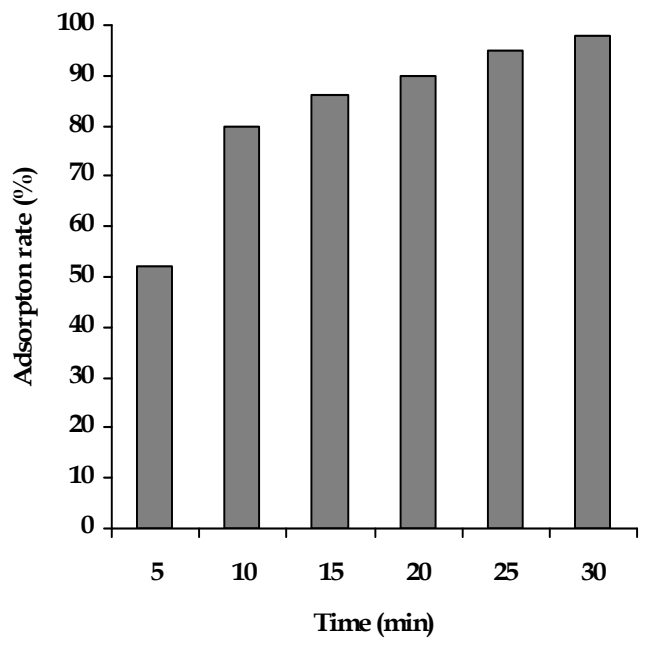

Fig. 2. Adsorption of bacteriophage PPST1 on S. Typhi SSH1 cells

\subsection{Thermal and pH sensitivity}

Thermal lability of bacteriophage PPST1 was investigated by thermal treatments at 50,60, 70,80 and $90^{\circ} \mathrm{C}$ for $30 \mathrm{~min}$ (Table 2). At $50^{\circ} \mathrm{C}$, only a small reduction of the bacteriophage was observed. In contrast, the bacteriophage titers decreased considerably at 60 and $70^{\circ} \mathrm{C}$. The higher temperature resulted in fewer bacteriophage titers. Heating at 80 and $90^{\circ} \mathrm{C}$ for 30 min completely inactivated the bacteriophage, thus phage titer could not be detected in the samples.

The stability of bacteriophage PPST1 was also investigated by incubating the bacteriophage overnight in a phosphate buffered saline solution at $\mathrm{pH}$ ranging from 2 to 12 . The bacteriophage maintained its infectivity when incubated in a $\mathrm{pH}$ range of from 4 to 10 . In contrast, the bacteriophage lost its infectivity completely at $\mathrm{pH} 3$ or below as well as at $\mathrm{pH}$ 11 or above. The highest stability of bacteriophage was observed at $\mathrm{pH} 7$ (Table 2).

\subsection{One step growth kinetics}

Multiplication parameters of the lytic cycle of bacteriophage PPST1 including latent period, burst period and burst size were determined from the dynamic change in the number of bacteriophage during one replicative cycle (Fig. 3). It was determined that bacteriophage PPST1 had latent and burst periods of ca. 30 and $150 \mathrm{~min}$, respectively. The burst size estimated from the one-step growth curve was about 79 PFU/infected cell (Fig. 3).

\subsection{Morphology, genome and protein composition}

Morphological characterization of bacteriophage PPST1 was examined by transmission electron microscopy. It was shown that the bacteriophage had an icosahedral head $(64 \pm 2.4$ $\mathrm{nm}$ in diameter) with a noncontractile tail of $157 \pm 8.6 \mathrm{~nm}$ long and $12 \pm 0.6 \mathrm{~nm}$ wide. No collar or tail appendages were observed (Fig. 1). 


\begin{tabular}{ccc}
\hline Treatment & $\begin{array}{c}\text { Initial bacteriophage } \\
\text { concentration } \\
(\log \text { PFU } / \mathrm{ml})\end{array}$ & $\begin{array}{c}\text { Final bacteriophage } \\
\text { concentration } \\
(\log \text { PFU } / \mathrm{ml})\end{array}$ \\
\hline $\begin{array}{l}\text { Heat }(\text { for } 30 \mathrm{~min}) \\
50^{\circ} \mathrm{C}\end{array}$ & 6.09 & 5.57 \\
$60^{\circ} \mathrm{C}$ & 6.04 & 3.62 \\
$70^{\circ} \mathrm{C}$ & 5.97 & 2.46 \\
$80^{\circ} \mathrm{C}$ & 6.08 & - \\
$90^{\circ} \mathrm{C}$ & 6.00 & - \\
$\mathrm{pH}($ for $1 \mathrm{~h})$ & & - \\
2 & 6.02 & - \\
3 & 5.98 & 3.96 \\
4 & 6.08 & 3.51 \\
5 & 6.00 & 4.83 \\
6 & 6.02 & 5.89 \\
7 & 6.04 & 4.93 \\
8 & 5.99 & 3.73 \\
9 & 6.03 & 2.67 \\
10 & 6.02 & - \\
11 & 5.97 & - \\
12 & 6.00 & \\
\hline
\end{tabular}

$\mathrm{a}=$ undetectable

Table 2. Sensitivity of bacteriophage PPST1 to temperature and $\mathrm{pH}$.

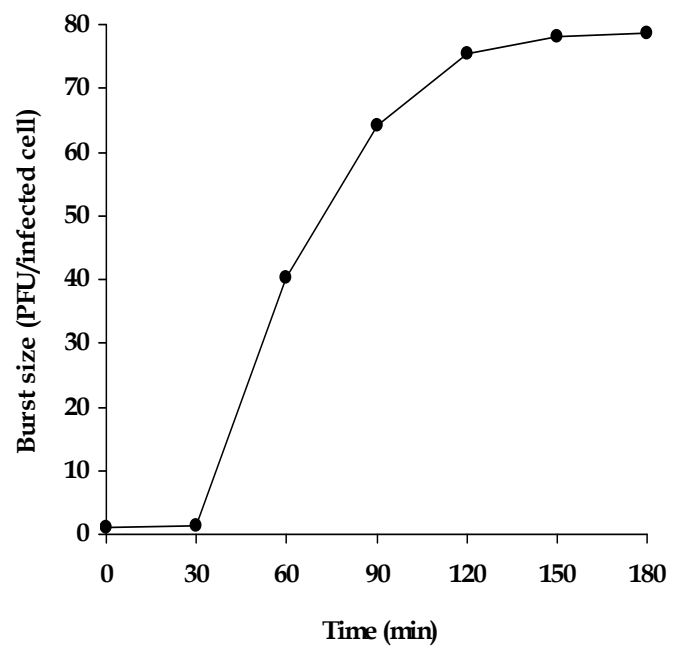

Fig. 3. One-step growth curve of bacteriophage PPST1.

The nucleic acid extracted from bacteriophage PPST1 was examined for its sensitivity to different nucleic acid digesting enzymes. It was found that the nucleic acid could not be digested either by Ribonuclease A or Nuclease $S_{1}$; however, it was sensitive to the restriction 
enzyme PstI (Fig. 4). The size of the nucleic acid as revealed by the pulsed-filed gel electrophoresis was ca. $70 \mathrm{~kb}$.

The protein composition of bacteriophage PPST1 was analyzed by SDS-PAGE and the result is shown in Fig. 5. Four protein bands were clearly detected in the SDS-PAGE gel. Based on sizes of protein standard SeeBlue Plus 2 (Invitrogen, Carlsbad, CA, USA), their estimated molecular masses were 81, 32, 24 and $15 \mathrm{kDa}$.

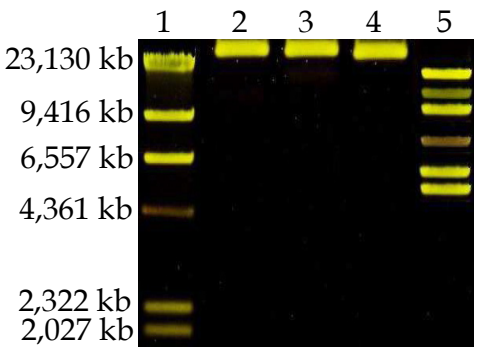

Fig. 4. Agarose gel electrophoresis of bacteriophage PPST1 nucleic acid. Lane 1, lambda DNA digested with HindIII marker; lane 2 uncut PPST1 nucleic acid; lane 3, PPST1 nucleic acid digested with Ribonuclease A; lane 4, PPST1 nucleic acid digested with Nuclease $S_{1}$, lane 5, PPST1 nucleic acid digested with PstI.

$188 \mathrm{kDa}$
$98 \mathrm{kDa}$
$62 \mathrm{kDa}$
$49 \mathrm{kDa}$
$38 \mathrm{kDa}$
$28 \mathrm{kDa}$
$17 \mathrm{kDa}$
$14 \mathrm{kDa}$

Fig. 5. SDS-PAGE analysis of bacteriophage PPST1 proteins. Lane 1, the protein standard SeeBlue Plus2, lane 2, proteins of bacteriophage PPST1.

\section{Discussion}

Typhoid fever caused by $S$. Typhi is a major pubic health problem worldwide, especially in developing countries. Although its incidence in the developed countries has been declining, the disease is still a frequent cause of death in parts of the world with poor sanitation (Murray, 1994). Until just recently, antibiotics were widely used to control S. Typhi infections; however, the emergence of antibiotic resistant $S$. Typhi in reducing drug efficacy 
has led to a need for alternatives to antibiotics in controlling infections as a result of the pathogenic bacteria. Bacteriophage therapy is one of the promising alternatives to control infections caused by drug resistant bacteria. This may be due to the fact that bacteriophages and antibiotics have different mechanisms of action (McAuliffe et al., 2007). Besides the ability to inhibit the growth of drug resistant bacteria, many attributes of bacteriophages make them more favorable than antibiotics for therapeutic purposes. They infect only their specific hosts, having no harm on normal microflora, and because of their host dependent multiplication, bacteriophages increase their numbers at the sites of infection, thereby increasing therapeutic efficacy. After their hosts are inactivated, bacteriophages tend to be rapidly cleared from bodies of treated organisms (Carlton, 1999; Matsuzaki et al., 2005) by innate immune mechanisms. Therefore, bacteriophage therapy may be considered an effective and safe therapeutic approach.

Bacteriophages generally reside in environments that are habitats for their host bacteria (McLaughlin et al., 2006; Sundar et al., 2009). Wastewater from Sappasitthiprasong hospital, Ubon Ratchathani, Thailand was ideal for isolation of bacteriophages in this study since the drug resistant $S$. Typhi strain SSH1 used as the main host in the present bacteriophage screening is a clinical strain isolated from a patient admitted to the hospital. When screening for bacteriophages to be used in bacteriophage therapy, bacteriophages with a broad host range spectrum within a species are more preferable because they can be effective against a large variety of a particular species. The narrow host specificity of bacteriophages can cause complexity in preparation of therapeutic phages. In some cases, combinations of several bacteriophages are required for therapeutic application. In this study, bacteriophage PPST1 was showed to be lytic to all of the tested $S$. Typhi strains, but not any other tested bacteria. Furthermore, among the sensitive bacterial strains, two were multi-drug resistant. S Typhi SSH1 is resistant to chloramphenicol, ampicillin, trimethoprim, tetracycline, streptomycin, sulfanilamide and ciprofloxacin while $S$ Typhi ATCC 19214 is resistant to chloramphenicol, tetracycline and streptomycin. These results suggest that bacteriophage PPST1 is a potential candidate for use as a therapeutic agent to control infectious diseases caused by drug resistant $S$. Typhi. Finding a lytic bacteriophage with a broad host range is not unusual. A number of studies have reported the isolation of lytic bateriophages with a broad host range. Vinod et al. (2006) isolated a Vibrio harveyi bacteriophage from shrimp farm water, which was virulent to all 50 strains of $V$. harveyi tested that were originally isolated from different sources such as seawater, hatchery water, shrimp farm water and sediment. Moreover, some bacteriophages were reported to be lytic to bacteria in more than one genera. For example, phage KPO1K2 infected several strains of Klebsiella pneumoniae and Escherichia coli (Verma et al., 2009).

From previous studies, Salmonella bacteriophages were found to be heterogeneous, comprising all of the three families of tailed bacteriophages, including Siphoviridae, Myoviridae and Podoviridae (Demczuk et al., 2004; McLaughlin, 2006; De Lappe et al., 2009). The criteria commonly used for the classification of bacteriophages to a particular group are bacteriophage genetic and morphological characteristics. The genome of bacteriophage PPST1 was double stranded DNA because it was resistant to Nuclease $S_{1}$, a single stranded DNA digesting enzyme, and Ribonuclease A, a RNA digesting enzyme, but sensitive to the restriction enzyme PstI, a double stranded DNA digesting enzyme. Transmission electron microscopy revealed that the bacteriophage was a tailed bacteriophage with an icosahedral 
head and a long noncontractile tail. Based on these characteristics, bacteriophage PPST1 can be tentatively classified as a member of the family Siphoviridae, according to the International Committee on Taxonomy of Viruses (Ackermann, 2005). There are several previously studied $S$. Typhi bacteriophages that have never been classified into a particular family due to the lack of genetic or morphological characteristics. The lytic bacteriophage specific to $S$. Typhi DMS 5784 was found to have an icosahedral head that was ca. 44 to $47 \mathrm{x}$ 43 to $51 \mathrm{~nm}$ in diameter and a very short tail. Since its genomic characteristic has been studied, no classification of the bacteriophage has ever been reported (Neukdee, 2007). The S. Typhi bacteriophage j2 studied by Mise et al. (1981) is a DNA lysogenic bacteriophage. The lack of its morphological information has impeded the classification of the bacteriophage.

Variations in nucleic acid sequence and numbers of genes and proteins of bacteriophages in the family Siphoviridae have been reported (Rohwer and Edwards, 2002). In this study, four proteins with molecular masses ranging from 15 to $81 \mathrm{kDa}$ were identified by SDS-PAGE analysis. However, their amino acid sequences and functions are still unknown. A detailed nucleic acid sequence analysis and identification of the open reading frames corresponding to the observed structural proteins are the subjects of future research.

Several studies have demonstrated that thermal and $\mathrm{pH}$ stability of bacteriophages varied depending on types of bacteriophage; therefore, it is of interest to investigate the stability of bacteriophage PPST1 in a wide temperature and $\mathrm{pH}$ range. These results demonstrate that bacteriophage PPST1 is stable in a broad $\mathrm{pH}$ range (4-10) and at a temperature as high as $70^{\circ} \mathrm{C}$ for at least $3 \mathrm{~min}$. These morphological characteristics may be useful in broad applications of bacteriophage therapy.

In conclusion, the data obtained from the present study clearly indicates that the bacteriophage PPST1 is a lytic bacteriophage capable of killing several strains of S. Typhi, including drug resistant strains. This property of the bacteriophage, together with its stability at a high temperature and over a wide $\mathrm{pH}$ range, makes bacteriophage PPST1 a potential alternative to antibiotics as a therapeutic agent for infections of drug resistant $S$. Typhi. Future research is needed to elucidate the most suitable condition for the application of this characterized bacteriophage in treating experimentally-induced drug resistant $S$. Typhi infection in animal models.

\section{Summary}

The emergence of drug resistant Salmonella Typhi has limited the efficacy of antibiotic based therapeutic approach. Bacteriophage therapy has recently been considered a promising approach to control infections caused by drug resistant bacteria. In this study, a lytic bacteriophage, specific to drug resistant $S$. Typhi strain SSH1, was isolated from hospital wastewater. The bacteriophage, designated PPST1, had broad host range within the species $S$. Typhi. It was lytic against all of the tested $S$. Typhi strains, but not any other tested bacteria. The bacteriophage was completely inactivated at 80 and $90^{\circ} \mathrm{C}$ for $30 \mathrm{~min}$ but was stable at $50{ }^{\circ} \mathrm{C}$ for $30 \mathrm{~min}$ and over a wide $\mathrm{pH}$ range (4 to 10). Approximately $80 \%, 90 \%$ and $98 \%$ of bacteriophage particles adsorbed to the host cells within 10, 20 and 30 min after infection, respectively. One-step growth kinetics of the bacteriophage showed that the latent and burst periods were 30 and $150 \mathrm{~min}$, respectively, and the burst size was about 79 
PFU/infect cell. As shown by transmission electron microscopy, the bacteriophage had an icosahedral head of ca. $64 \mathrm{~nm}$ in diameter and a long noncontractile tail of ca. $157 \mathrm{~nm}$ long and $12 \mathrm{~nm}$ wide. Its genome was double stranded DNA, $70 \mathrm{~kb}$ in size. It was classified as a member of the family Siphoviridae. A total of 4 bacteriophage proteins with molecular masses of 15, 24, 32 and $81 \mathrm{kDa}$ were detected by sodium dodcyl sulfate-polyacrylamide gel electrophoresis. Knowledge of the properties of bacteriophage PPST1 may be useful for the development of the bacteriophage to use as therapeutic agents against infections as a result of drug resistant $S$. Typhi

\section{References}

Ackermann, H.W. (2005). Bacteriophage classification, In: Bacteriophages: Biology and applications, E. Kutter \& A. Sulakvelidze, (Ed.), 67-90, CRC Press, ISBN 978-0-84931336-3, Boca Raton, FL, USA

Bruttin, A. \& Brussow, H. (2005). Human volunteers receiving Escherichia coli phage T4 orally: a safety test of phage therapy. Antimicrobial Agents and Chemotherapy, Vol. 49, No. 7, (July 2005), pp. 2874-2878, ISSN 1098-6596

Capparelli, R., Parlato, M., Borriello, G., Salvatore, P. \& Iannelli, D. (2007). Experimental phage therapy against Staphylococcus aureus in mice. Antimicrobial Agents and Chemotherapy, Vol.51, No.8, (August 2007), pp. 2765-2773, ISSN 1098-6596

Carlton, R.M. (1999). Phage therapy: past history and future prospects. Archivum Immunologiae et Therapiae Experimentalis, Vol. 47, No.5, (September 1999), pp. 267274, ISSN 1661-4917

Caso, J.L., De Los Reyes-Gavilan, C.G., Herrero, M., Montilla, A., Rodriguez, A. \& Suarez, J.E. (1995). Isolation and characterization of temperate and virulent bacteriophages of Lactobacillus plantarum. Journal of Dairy Science, Vol.78, No.4, (April 1995), pp. 741-750, ISSN 1525-3198

Chang, H.C., Chen, C.R., Lin, J.W., Shen, G.H., Chang, K.M., Tseng, Y.H. \& Weng, S.F. (2005). Isolation and characterization of novel giant Stenotrophomonas maltophilia phage ФSMA5. Applied and Environmental Microbiology, Vol.71, No.3, (March 2005), pp. 1387-1393, ISSN 1098-5336

Chhibber, S., Kaur, S. \& Kumari, S. (2008). Therapeutic potential of bacteriophage in treating Klebsiella pneumoniae B5055-mediated lobar pneumonia in mice. Journal of Medical Microbiology, Vol.57, No.12, (December 2008), pp. 1508-1513, ISSN 1473-5644

Coates, A., Hu, Y., Bax, R. \& Page, C. (2002). The future challenges facing the development of new antimicrobial drugs. Nature Reviews Drug Discovery, Vol.1, No.11, (November 2002), pp. 895-910, ISSN 1474-1776

De Lappe, N., Doran, G., O'Connor, J., O'Hare, C. \& Cormican, M. (2009). Characterization of bacteriophages used in the Salmonella enterica serovar Enteritidis phage-typing scheme. Journal of Medical Microbiology, Vol.58, No.1, (January 2009), pp. 86-93, ISSN 1473-5644

Demczuk, W., Ahmed, R. \& Ackermann, H.W. (2004). Morphology of Salmonella enterica serovar Heidelberg typing phages. Canadian Journal of Microbiology, Vol.50, No.10, (October 2004), pp. 873-875, ISSN 1480-3275

Deresinski, S. (2009). Bacteriophage therapy: exploiting smaller fleas. Clinical Infectious Diseases, Vol.48, No.8, (April 2009), pp. 1096-1101, ISSN 1058-4838 
Lu, Z., Breidt, F., Fleming, H.P., Altermann, E. \& Klaenhammer, TR. (2003). Isolation and characterization of a Lactobacillus plantarum bacteriophage, $\Phi \mathrm{JL}-1$, from a cucumber fermentation. International Journal of Food Microbiology, Vol.84, No.2, (July 2003), pp. 225-235, ISSN 0618-1605

Matsuzaki, S., Rashel, M., Uchiyama, J., Sakurai, S., Ujiara, T., Kuroda, M., Ikeuchi, M., Tani, T., Fujieda, M., Wakiguchi, H. \& Imai, S. (2005). Bacteriophage therapy: a revitalized therapy against bacterial infectious diseases. Journal of Infection and Chemotherapy, Vol.11, No.5, (October 2005), pp. 211-219, ISSN 1437-7780

McAuliffe, O., Ross, R.P. \& Fitzgerald, GF. (2007). The New Phage Biology: From Genomics to Applications, In: Bacteriophage: Genetics and Molecular Biology, S. McGrath \& D. van Sinderen, (Ed.), 1-42, Caister Acadamic Press, ISBN 978-1-904455-14-1, Norfolk, UK

McLaughlin, M.R., Balaa, M.F., Sims, J. \& King, R. (2006). Isolation of Salmonella bacteriophages from swine effluent lagoons. Journal of Environmental Quality, Vol.35, No.2, (February 2006), pp. 522-528, ISSN 0047-2425

Mise, K., Kawai, M., Yoshida, Y. \& Nakamura, A. (1981). Characterization of bacteriophage j2 of Salmonella typhi as a generalized transducing phage closely related to coliphage P1. Journal of General Microbiology, Vol.126, No.2, (October 1981), pp. 321326, 0022-1287

Murray, P.R. (1994). Enterobacteriaceae, In: Medical Microbiology, R. Farrell, (Ed.), 227-240, Mosby Year Book Inc., ISBN 0723420106, London, UK

Nakai, T. \& Park, S.C. (2002). Bacteriophage therapy of infectious diseases in aquaculture. Research in Mirobiology, Vol.153, No.1, (January 2002), pp. 13-18, ISSN 0923-2508

Nuekdee, K. (2007). Isolation and partial characterization of Salmonella typhi-specific bacteriophage. Khon kaen University Science Journal, Vol.35, No.3, (July 2007), pp. 162-169, ISSN 0125-2364

Paterson, W.D., Douglas, R.J., Grinyer, I. \& McDermott, L.A. (1969). Isolation and preliminary characterization of some Aeromonas salmonicida bacteriophages. Journal of the Fisheries Research Board of Canada, Vol.26, No.3, (March 1969), pp. 629-632, ISSN 0015-296x

Rohwer, F. \& Edwards, R. (2002). The Phage Proteomic Tree: a genome-based taxonomy for phage. The Journal of Bacteriology, Vol.184, No.16, (Auguat 2002), pp. 4529-4535, ISSN 1098-5530.

Rowe, B., Ward, L.R. \& Threlfall, EJ. (1997). Multidrug-resistant Salmonella typhi: a worldwide epidemic. Clinical Infectious Diseases, Vol.24, Suppl. 1, (January 1997), pp. S106-S109, ISSN 1058-4838

Sundar, M.M., Nagananda, G.S., Das, A., Bhattacharya, S. \& Suryan, S. (2009). Isolation of host-specific bacteriophages from sewage against human pathogens. Asian Journal of Biotechnology, Vol.1, No.4, (October 2009), pp. 163-170, ISSN 1996-0700

Thamniamton, W., Boonsarn, V., Phumkhachorn, P. \& Rattanachaikunsopon, P. (2010). Isolation and characterization of a bacteriophage specific to drug resistant Klebsiella pneumoniae DR1. International Journal of Current Research and Review, Vol.2, No.4, (April 2010), pp. 30-43, ISSN 0975-5241

Trung, N.D., Suthisarnsuntorn, U., Kalambaheti, T., Wonglumsom, W. \& Tunyong, W. (2007). Antimicrobial susceptibility patterns and phage types of Salmonella typhi 
from Vietnam. Southeast Asian Journal of Tropical Medicine \& Public Health, Vol.38, No.3, (May 2007), pp. 487-492, ISSN 0038-3619

Verma, V., Harjai, K. \& Chhibber, S. (2009). Characterization of a T7-like lytic bacteriophage of Klebsiella pneumoniae B5005: a potential therapeutic agent. Current Microbiology, Vol.59, No.3, (September 2009), pp. 274-281, ISSN 1432-0991

Vinod, M.G., Shivu, M.M., Umesha, K.R., Rajeeva, B.C., Krohne, G., Karunasagar, I. \& Karunasagar, I. (2006). Isolation of Vibrio harveyi bacteriophage with a potential for biocontrol of luminous vibriosis in hatchery enviroments. Aquaculture, Vol.255, No.1-4, (May 2006), pp. 117-124, ISSN 0044-8486

Vinodkumar, C.S., Neelagund, Y.F. \& Kalsurmath, S. (2005). Bacteriophage in the treatment of experimental septicemic mice from a clinical isolate of multidrug resistant Klebsiella pneumoniae. Journal of Communicable Diseases, Vol.37, No.1, (March 2005), pp. 18-29, ISSN . 0019-5138 
(C) 2012 The Author(s). Licensee IntechOpen. This is an open access article distributed under the terms of the Creative Commons Attribution 3.0 License, which permits unrestricted use, distribution, and reproduction in any medium, provided the original work is properly cited. 